\title{
THE POLITICAL-RELIGIOUS RELATIONS BETWEEN THE KURDS AND THE OTTOMAN EMPIRE
}

\author{
Meirison \\ Imam Bonjol State Islamic University Padang, Indonesia \\ E-mail: meirison@uinib.ac.id
}

\begin{abstract}
The Kurds are an ethnic group that has experienced significant friction with other countries, such as Persia, Arabia, the Mongols, and Turkey. However, the Kurds and the Ottoman Empire have established completely distinct relations, including the mutual attraction of the Islamic Faith, school of thought, and the problem of nationalism. Although Islam does not discern according to the ethnicity people belong to, it is a devotion that distinguishes their degree before God. Therefore, this article attempts to examine how the Kurds have been able to survive under the auspices of the Ottoman Empire, which was formerly considered as a substitute for the previous Islamic caliphate that ruled based on shari'a. The study discovered that the political and legal transformation in the body of the Ottoman Empire made the Kurds extremely depressed and agitated. This brought about the rise of their nationalism and intention to establish an independent state. Unfortunately, it was difficult to realize since the region's map is shaped by the winning countries of World War I, which did not recognize the so-called Kurdistan State. Also, the surrounding countries, such as Turkey, Iran, Syria, and Iraq, did not want to lose their territory.
\end{abstract}

Keywords: Kurds; Turkey; Nationalism; Islam.

\section{Introduction}

The Kurdish-Turkish conflict has aged decades in the $21^{\text {st }}$ century since the insurgency began. If we viewed from a wider historical perspective, this conflict rooted back from nationalism and sectarianism issues that had long occupied the countries in dispute. Thus a multi-perspectives discussion is considered significant because it will result in positive consequences, or at least it could reduce tensions and strengthen bilateral ties to diminish the impact of the crisis in the Middle East and the future of Muslims in the region. 
The Kurds initially had a long and strong relationship with the Ottoman Empire. Yet, after a change in the Empire, specifically after the Sultan Abdul Hamid II era, the Kurds mislaid the focus of nationalism, which had strengthened previous tribal sentiments. It was also triggered by the projection of western nationalism, which divided the nation based on territory. Owing to this, the Kurds split up into several regions as mapped by Britain and France, such as Syria, Iraq, Iran, and Turkey.

In 1984, the Kurdish-Turkish conflict marked its new phase along with political changes in Turkey. Since then, the conflict has taken place in the form of guerrilla movements and limited warfare between Turkish government forces and the PKK (The Kurdish Workers Party). ${ }^{1}$ For the Turkish government, unity and territorial integrity cannot be contested. At the same time, PKK demanded the cultural and political rights for Kurds in the form of federalism or separation of government. ${ }^{2}$ This conflict had resulted in more than 20.000 deaths. In 3000, village schools were closed. As a result, 1.5 million children did not get access to education. More ironically, over and above, 500 health centers must be closed, and around 3 million people should migrate and leave their homes. ${ }^{3}$

In this article, the author examined the historical dynamics of relations between Kurds and Turks through several primary sources. One of them is a book by Abdussatar Tahir Syarif, al-Mujtama' alKurdī: Diräsah Ijtimáàyah Thaqäfah Siyāsah, which describes the history of Kurds originating from Central Asia and settles in the mountainous region of Zagros, then lived across Iraq, Persia, and Syria. ${ }^{4}$ Another source of literature is a book written by Abdullah Alyawi, entitled Kurdistan fi 'Abd Dawlah 'Uthmānìah 1851-1914

\footnotetext{
1 Nimet Beriker-Atiyas, "The Kurdish Conflict in Turkey: Issues, Parties, and Prospects," Security Dialogue, Vol. 28, No. 4 (December 1997), 439-452.

2 Maryani Kharudakī, al-Kurd wa al-Siyāsah al-Khärijiyah al-Amrikeìyah (Beirut: Dār alFārāb̄ì, 2003), 44.

3 Mehmet Orhan, "Kurdish Rebellions and Conflict Groups in Turkey during the 1920s and 1930s," Journal of Muslim Minority Affairs, Vol. 32, No. 3 (September 2012), 339-358.

${ }^{4}$ Richard Foltz, "The 'Original' Kurdish Religion? Kurdish Nationalism and the False Conflation of the Yezidi and Zoroastrian Traditions," Journal of Persianate Studies, Vol. 10, No. 1 (June 1, 2017), 87-106.
} 
Diräsab Tärikhiyah. This book depicts the changes that occurred in the Ottoman Empire during the Tanzimat process. ${ }^{5}$

\section{A Brief History of Kurdistan}

The Kurdistan term is composed of two words, Kurdish and Stan, which means the Kurdish State. Kurdistan also means Kurdish or Kurdish land, which shows ethnicity and nationality. The Islamic Encyclopedia shows that the Kurdistan laf 2 (pronunciation) is the name of the people who inhabit its territory, and the name prevails. Kurdistan is a vast territory and has no political boundaries. A Russian historian, Nikitin, said, "the Kurdistan lafz was pronounced for the first time by a man named Sanjar, the last king of the Seljuq Turk". ${ }^{6}$ The name of Kurdistan referred to a province under his control in the $12^{\text {th }}$ century $\mathrm{AD}$. There stretched several regions separated by Zagros mountain.

The area of Kurdistan was formerly called the Jazira mountain or Diyar Bakir. Al-Qazwini was the first historian who introduced the term of Kurdistan in his notable book Nu₹hat al-Qulüb in $740 \mathrm{H}, 14^{\text {th }}$ century AD. ${ }^{7}$ Although some differences arose because some experts disagree about the naming of Kurdistan, the dissent was finally no longer applied after the territorial boundaries of Kurdistan were determined. ${ }^{8}$ Kurdistan does not have an independent political integration, ${ }^{9}$ but it covers several regions such as Turkey, Iraq, Iran, Syria, and Azerbaijan. Generally, the Kurdistan region lies from the Black Sea mountain, next to the Caucasus, Siwas (Sivas), Erzurum from the north, Mur'isy in the north, and Karamansyah from the east, Mosul and Diyar Bikr from the south. ${ }^{10}$ In these regions, Kurdish

\footnotetext{
${ }^{5}$ Ebru Aykut, "Judicial Reforms, Sharia Law, and the Death Penalty in the Late Ottoman Empire," Journal of the Ottoman and Turkish Studies Association, Vol. 4, No. 1 (2017), 7.

${ }^{6}$ Foltz, "The 'Original' Kurdish Religion?”.

7 W. G. Elphinston, "Kurds and Kurdistan," International Affairs, Vol. 25, No. 2 (April 1949), 235-235.

8 Meirison, "Kurds, Islam, and Secularism," Jurnal Madania, Vol. 23, No. 1 (June 2019), 46-60,

${ }^{9}$ Kharudakī, al-Kurd wa al-Siyāsah, 142.

${ }_{10}$ Donald Quataert, The Ottoman Empire, 1700-1922 (Cambridge, UK; New York: Cambridge University Press, 2005).
} 
tribes live scattered in several countries and are considered as classical people. $^{11}$

The strategic geographical location shapes Kurdistan as trade traffic linking the Persian with the Black Sea. Not only as of the main trade routes, but the Kurdistan region is also rich in natural resources, which makes it a strategic area for military defense. At the beginning of the $16^{\text {th }}$ century $\mathrm{AD}$, Kurdistan had become a fierce arena of struggle because this region had been a conquest of conquerors' lands since ancient times, including to the Ottoman Empire and the Safavid Kingdom. This had made the Kurds as the political object of the two countries. It was started with the agitation, incitement, partisanship, and promises of wealth and power from both parties. All of this could not be separated from the fanaticism of school in Islam. ${ }^{12}$

Kurdistan is a fertile land for power struggles between Safavid and Ottoman Empire. In 1507 AD, the Shah's (Ismail Shafawi) army invaded Kurdistan territories and occupied it in 1501-1534 AD. At that time, Kurdistan was ruled by several dukes and independent Kurdish families. Safavid destroyed these small kingdoms, so Safavid ruled over the dukes of Kurdistan with violence and oppression. Besides, the Safavid kingdom also burdened the Kurds with heavy taxes and forced labor. Safavid controlled the area straight without representing it to the dukes whose territory had just been occupied. Dissimilarities also catalyze this in schools, where Kurdish tribes are Sunnī Shāfîīyah, while Shafawi is Shi'ite. ${ }^{13}$

\section{Fluctuations in Kurds-Ottoman Empire Relation}

The Kurds-Ottoman Empire relations have taken place for centuries since the agreement between Sultan Salim I in 1514 and the Kurdish duke, Sharaf al-Din Khan Bedlisi. The Duke coordinated the Kurds to side with the Ottoman Empire in the war against the

\footnotetext{
11 'Abd Allah al-'Alyāwī, Kurdistān fi' 'Ahd Dawlah 'Uthmānìyah 1851-1914 Dirāsah fì alTärikh al-Siyāsì (Sulaimaniyah: Matba’ah Baghdad, 2005), 221.

${ }^{12}$ Edmund Gharīb, al-Harakah al-Qawmìyah al-Kurdīyah (Beirut: Dār al-Nahār, 1973), 9.

13 Muhạmmad Amīn Zakī, Tärikeh al-Duwal wa al-Imārah al-Kurdīyah (Kairo: Dār alMiṣr, 1948), 263.
} 
Safavid Kingdom. ${ }^{14}$ In return, the Kurds were given the right to autonomy in regulating and controlling the area they lived in. ${ }^{15}$

The Kurds had particularly played a significant role in several wars fought by the Ottoman Empire. Among the most decisive battles were the Chaldiran war, the Cremia war, the Russian-Ottoman war 1877-1878 AD, and the Turkish war of independence in 19191922 AD, which ended with World War I in 1914 AD. ${ }^{16}$ Although Kurdish had always supported the Ottoman Turks in many wars, the loyalty of the Kurds was frequently overlooked. The relationship between the Kurds and the Ottoman Turks was somewhat unique. The similarity of the Islamic school of faith between the two was often the reason for the close relations between the two parties. Occasional political tension between the Kurds with the Ottoman Empire ensued, but the tension depleted again after. Some incidents, such as the Italian expansion in Libya in 1911 and the British occupation of Iraq, had reawakened Kurdish loyalty to the Ottoman.

Frequently, the Kurds did not bear a grudge of the abuse of the Ottoman rulers, which caused their sense of solidarity injured. This was obvious when there was a call for jihad against the invaders who began to expand the regions in the Middle East, which were the basis of Ottoman Emperor power. The call for jihad forced Kurds in Iraq to fight to defend their territory under the name of the Ottoman Empire. The invaders convinced them to rebel against the Ottoman with compensation to hand over power in Iraqi territory to the Kurds. ${ }^{17}$

Britain promises to surrender Iraqi territory to the Kurds after escaping Ottoman rule did not make the Kurdish leaders in Iraq persuaded. The Kurds in Iraq agreed not to help Britain. Instead, they trapped its troops in Iraq, which resulted in Britain to lose 40,000 military personnel who were drowned in the swamps. As a response to the call for jihad, many young Kurds moved south during World War I from the Mosul region. All Kurdish tribes responded to the call for jihad against the British invaders triggered by religious sympathy

\footnotetext{
${ }_{14}$ John Andrew Boyle and A. J. Arberry (eds.), The Cambridge History of Iran. Vol. 5: The Seljuq and Mongol Periods, Repr. (Cambridge: Cambridge Univ. Press, 2007), 145.

15 Basil Nikitin, al-Akrād (Kairo: Dār Sahāb, 2018), 23.

16 Muhammad Farīd Bek, Tärikh al-Dawlah al-'Alìyah al-'Utmānìyah (Beirut: Dār alNafāis, 2009), 157.

17 Akmal al-Dīn Iḥsān Ūghalī, al-Dawlah al-Uthmānìyah: Tārikh wa Hadạrah (Istanbul: Markaz Abhāth al-Tārīkh, 2011), 224.
} 
to help their brothers, Arab-Muslims in the South. They were also loyal to the Ottoman Empire. ${ }^{18}$ However, during the crisis in the Ottoman Empire as a result of the secularization revolution of the Young Turk, together with the idea of nationalism based on the nation-state propagated by Western Europe, Kurdish tribes scattered in many regions should choose to let themselves off of the Ottoman or be forced to join the nation-state.

\section{Political-Religious Aspects of Kurds-Ottoman Empire Relations}

As a consequence of Shafawi Shah's political behavior, which ignored Kurdish families in running the government in their territories, the Kurdish people started to gaze at the Ottoman Empire, who tended to have similarities in the school of thought. Sultan Salim, I reacted to this situation in the best way by exploiting the tumult and commotion for the benefit of the Ottoman Empire. The scholars and the Arab community also supported the rebellion. They sent an envoy to Sultan Salim I to fight the Safavid kingdom and stop the fanaticism of the schools which imposed Shiite onto the Shafi'ite schools. Sultan Salim, I sent a letter to Syah Ismail. I said in half cursed, "fight the infidels and polytheists, suppress the enemies of religion, conquer the Pharaohs by the Sultan of the Jawara (Warrior/al-Ghāzī and Mujahideen).,"19

Sultan Salim, I sent an envoy, a person close to him named Idris al-Badlisi, a historian, an accomplished diplomat to be departed to Kurdistan so that the Ottoman Empire could get support and help from the Kurdish tribes. With his expertise, Shaykh Badlisi could go back safely and brought a text of agreement from the Kurdish tribes in the Kurdistan region. ${ }^{20}$ The dukes of Kurdistan conveyed their loyalty to the Ottoman Empire. In this way, Badlisi succeeded in his mission of embracing all the tribes and dukes, and Kurdish and Arabic scholars to support and assist the Ottoman Empire in the war against the Safavid kingdom. Sultan Salim issued an order by giving

\footnotetext{
18 Suraiya Faroqhi and Halil İnalc1k, eds., An Economic and Social History of the Ottoman Empire, Vol. 2: 1600-1914, 1. paperback ed., reprinted. (Cambridge: Cambridge Univ. Press, 2004), 553

${ }^{19}$ Stanford J. Shaw and Ezel Kural Shaw, History of the Ottoman Empire and Modern Turkey. Vol. 1: Empire of the Gazis: The Rise and Decline of the Ottoman Empire: 12801808, Reprinted. (Cambridge: Cambridge Univ. Press, 1995), 131.

${ }^{20}$ Khalīl 'Alī Murād, Tārìkh al-Irāq al-Idārì wa al-Iqtisāàì fì 'Ahd al-Uthmānī 1638-1750 (Baghhad: Jāmi‘at al-Baghdād, 1875), 67-77.
} 
power to the Badlisi in determining the structure and officials of the Kurdistan government to be appointed after winning the war.

After ensuring the loyalty of the Kurd tribes, Sultan Salim I began to leave for the Shafawi region on the 15th of Muharram 920 $\mathrm{H} / 1514 \mathrm{AD}$ to rule that kingdom. There was a fierce war on the coast of Chaldiran. The Kurds had contributed to Sultan Salim's victory against Ismail Shafawi. ${ }^{21}$ After winning the battle, Sultan Salim I immediately entered the capital of the Safavid kingdom located in Tabriz city on September 4, 1514 AD. The year of 1514 was a historical period in the development of the Ottoman Empire and its relationship with the Kurds because a part of the Kurdistan region was under the authority of the Ottoman Empire. As compensation for Kurdish assistance to the Ottoman Empire, the Ottoman Daula recognized the legality of the leadership of the Kurdish dukes over the Kurdistan region for generations. To keep the Kurdish tribes loyal, Sultan Salim I issued a letter of agreement with the Kurds in 1515 AD which said:

a. All Kurdistan dominions were set free following the previous agreement;

b. The leadership relay was inherited from a father to a son following the customs of the Kurdish tribes;

c. The Kurds should participate in all forms of war that the Ottoman Empire had inflicted on them;

d. The Ottoman Empire was obliged to defend the Kurds from all the dangers that threatened them both internally and externally;

e. Kurds were required to provide financial assistance to the Ottoman Empire. ${ }^{22}$

After the Chaldiran war, Kurdish and Ottoman cooperation in conquering the Shafawi fortress in the Kurdistan region continued. Kurdistan soldiers and champions participated as the key role in every battle involving the Ottoman Empire, such as the conquest of Mardin city in October 1515 AD, and the Quj Hishar war in 1516 AD. Then one by one, the Safavid fortresses such as Erxenî, Sanjar, Tal Afar (now Iraq), Jarmuk (Armenia), Saifir Bek, Bira Jak, Mosul, and Erbil

${ }^{21}$ Garnik Asatrian, "Prolegomena to the Study of the Kurds," Iran and the Caucasus, Vol. 13, No. 1 (2009), 1-57.

22 Aḥmad 'Abd al-Rahịm 'Abd al-Raḥìm Muṣtafā, Fī Ușūl al-Tārìkh al-Uthmānì (Kairo: Dār al-Shurūq, 1982), 235. 
collapsed. This is the beginning of a new chapter in the history of Kurdish-Ottoman relations that can be seen in the following aspects.

\section{Religious Empathy}

One aspect of building political-religious relations of the Kurdish-Ottoman is religious empathy. It has been written in the history that Kurdish is guided by Islam and its teachings. The leader of the Kurdish tribe named Jaban traveled thousands of kilometers to meet the Prophet Muhammad in Yathrib (Medina) where he declared his Islam in the presence of Prophet Muhammad. He was the first Kurdish ambassador to the Islamic State of Medina. Ever since the Kurdish traders flocked to the Prophet Muhammad to declare their Islam. So, the existence of Islam in Kurdistan in the early period of the Prophet Muhammad's da'wah (Islamic preaching) in Medina is no doubt. When the conquest of Persia and Roman territories was carried out during the time of Umar bin Khattab, Kurdish youths had become pioneers for Muslims in Iraq and surrounding.

Islam penetrated all regions of Kurdistan with peace, except in the territory of Syaharzur, which was part of Persian territory. Kurdistan was the most open region in accepting Islam. Over the centuries, the Kurds had proven their loyalty to Islam. The Kurdish tribe had transformed into the spirit of Islam and the army of the Khilafah Islamiyah for centuries. They guarded the borders of Islam territory from the threat of external enemies of Islam. the Kurdish tribe also had a stake in building Islamic civilization in the fields of scientific, cultural, economic, and physical developments. The Kurdish scholars had also played a pivotal role in the fields of Arabic, interpretation, fiqh, Hadīth, manners, and dates, especially science and logic. ${ }^{23}$ The Kurdish tribe's contribution to advancing Islamic civilization is undeniable. Kurdistan society is a tolerant society that can live peacefully with other religious communities and ethnic groups. The Kurds are $95 \%$ of Sunni in which the rest 5 percent is composed of Christians and other sects, such as al-Yazidiyah, Alawìyah, al-Shabak, al-Kakaīyah, and Ahl al-Haq.

A strong Islamic empathy among the Kurds is inseparable from the practice of Sufism in the region, which has encouraged the Kurdistan community to have high adherence to Islam. The role of the ulema or Muslim scholars and the tariqa sheikhs was crucial in

23 Some notable scholars of Kurds are Ibn Taymiyah, Ibn Qayyim al-Jawzìyah, Ḥasan al-Baṣrī, Syafan, Ṣalāh al-Dīn al-Ayyūbī, Afḍal, Min Kamān. 
guiding the Kurdish community to the conditions under which Islam became a world view in their life activities. The community leaders also played a substantial role in making strategic decisions in economic, social, cultural, and politics. The practice of Sufism in Kurdistan has spread since the $4^{\text {th }} \mathrm{H} / 11$ AD. The tariqa (Mystical method) spread among the Kurds are:

First, the Qādiriyah Tariqa is a tariqa ascribed to Shaykh 'Abd al-Qādir al-Jìlānī (1166 AD/ $571 \mathrm{AH})$. This tariqa was spread out in Kurdistan by Shaykh al-Nudhī (Barzanjì). His influence dispersed widely to all corners of Kurdistan so that there were several houses to practice the tariqa led by shaykhs who had a particular position among society.

Second, the Naqshbandīyah Tarekat is ascribed to Shaykh Bahā' al-Dīn Muhammad b. Jalāl, known as the Shah Naqashaband. The reformer of the Naqsyabandi Tarekat in Iraq and the Islamic world was Shaykh Ḍiyā’ al-Dīn Abū Khālid b. Husayn Shahzurī al-Shāfi ‘̄i known as Mawlanā Khālid al-Naqshabandī, born in $1779 \mathrm{AD}$ in the village of Qarah Dagh in the south of Sulaimaniyah (Iraq). Naqshbandiyah Tarekat in Kurdistan had remarkably developed in 1811-1820. After the return of Shaykh Khālid to Sulaymaniyah, many tariqa students gathered to study with him. His influence in Kurdistan was almost equal to that of Sheikh 'Abd al-Qādir al-Jilānī. Many ethnic groups adopt Naqshbandī Tariqa, even in Southeast Asia, such as Malaysia and Indonesia. ${ }^{24}$

\section{Patron-Client}

The political-religious ties of the Kurdish-Ottoman were built by aspects of patron-client relations, as the Kurds believed that the Ottoman Empire was the successor to the Islamic Khilafah, which rooted back at the caliphate of the companions of the Prophet. Kurdish people considered the Ottoman sultan to be a symbol of Islamic leadership that reminded them of al-khulafä' al-räshidün and Muslim leaders in the early Islamic period. This conviction was strengthened in the era of Abdul Hamid II (1876-1909), which had succeeded in uniting Muslims under the authority of the Ottoman Empire with the spirit of Pan-Islamism.

\footnotetext{
${ }^{24}$ Muhammad Shodiq, "Eksistensi dan Gerakan Dakwah Tarekat Siddîqîyah di Tengah Masyarakat Urban Surabaya," Teosofi: Jurnal Tasawnf dan Pemikiran Islam, Vol. 5, No. 2 (2016), 346.
} 
The patron-client relationship in Kurd-Ottoman relations is indeed not absolute. At one time stretched and in another time, it strengthened again. The revival of the Kurdish spirit was often triggered by a feeling of similarity of religion and patron of the Ottoman Empire as an extension of the Islamic caliphate. When the Russian-Ottoman War erupted in 1877-1878 AD, Shaykh al-Islām Hasan Khayr al-Dīn issued two fatwas; the first, the call for the holy jihad which requested Muslim to join in the war, and the second, award the title of al-Ghāzì to Sultan Abdul Hamid II. Both of these fatwas were very influential in raising sympathy from the Kurds. Shaykh 'Ubād Allah al-Nahrī answered the fatwa immediately ${ }^{25}$ by gathering 300 military personnel consisting of his students (tariqa students) in which he led the front-line in the battle with courage. Together with this Shaykh 'Ubād Allah al-Nahrī, there was the Hamawandi family who was famous for their courage and determination, and they fought on the side of the Ottoman Empire. Sultan Abdul Hamid II was proud of the heroism of the Shaykh and his students; therefore, he gave them vast agricultural land in the Baziyan region. ${ }^{26}$

In Sulaimaniyah, there was Syaikh Kak Ahmad, ${ }^{27}$ who had established good relations with Sultan Abdul Hamid II. When the Russian-Ottoman war broke out, the Shaykh answered the call of jihad and sent his students under the leadership of Shaykh Sacid to join the war against Russia. Besides, other Kurdish tribes were fighting under the guidance of Badar Khan Beik al-Kabir. It was not only Kurdish men who fought against the enemy but also Kurdish women who were led by Kurdish woman heroine, named Qurrah Fātimah, with 500 Kurdish cavalries. ${ }^{28}$ This elite force consisting of women was very instrumental in defending the Ottoman Empire from foreign and domestic threats. The courage of this Kurdish

\footnotetext{
${ }^{25} \mathrm{He}$ is a highly respected leader in Kurdistan with high spiritual authority. He was also called Abū al-Kurd (the father of Kurds).

26 Kamāl Muzhar Ahmad, Dawr al-Sha'b al-Kurdì fì Thawrah al-Ishrīn al-Iräqīyah (Baghdad: Maṭba'at al-Hawādith, 1978), 92-93.

${ }^{27} \mathrm{He}$ is Syaikh Nudi or Nudhi, one of the dominant Qutub Tariqa al-Iliyah alQādirìyah in Kurdistan. He was born in1207 H in the city of Sulaimaniyah, Iraq. Nudi studied with his father who was known for his mastery of religious science and had good relations with Abdul Hamid II.

28 al-'Alyāwī, Kurdistān fì 'Ahd Dawlah 'Uthmānīyah, 245-253.
} 
heroines was spread in Egyptian newspapers at that time. ${ }^{29}$ This patronage is reinforced by the obligation to obey the Muslim leaders who implement the Islamic Shari'a and the forbidden rebellion to the legitimate government. ${ }^{30}$

The fidelity of the Kurds was concluded when the TurkishRussian war broke out where they involved in security guard in Kurdistan and protection of the borders from various kinds of disruptions. Thus, Sultan Abdul Hamid II ordered to form an army consisting of Kurds in 1891 AD. This new force was formed and trained according to the Russian Cossack troop training model. Appeals were made by Ottoman Empire statesmen who directly went to the field to deal with Kurdish tribes. This was immediately responded by the Shaykhs of Sufism and Kurdish militants to join the Ottoman Empire in defending the country. ${ }^{31}$

\section{Crisis in Kurds-Ottoman Empire Relations}

Ittihad ve Terakki Cemiyeti is an opposition party that overthrew Sultan Abdul Hamid II in 1909, with support from Jews and European countries which caused the wrath of the people and the entire Islamic world because the Sultan Abdul Hamid II's destruction meant destroying the Ottoman Caliphate, a symbol of the leadership of Muslims throughout the world. This coup attempt marked the political divisions of the Muslims and the division of their territories into many countries and the exploitation of the natural wealth of Muslims, but most importantly, the intentions and objectives of the Europeans were exposed, which are freezing the implementation of Islamic Shari'a. ${ }^{32}$

Although this freeze was not applied, the main principles of the implementation of Shari'a itself were no longer exist. ${ }^{33}$ Civil law and Islamic criminal law were no more applicable in some Muslimpopulated areas. Kurds considered this as a Western and Jewish conspiracy against Muslims. ${ }^{34}$ Ittihad ve Terakki Cemiyeti mobilized the

\footnotetext{
29 Rauf Syanawi, al-Naz'ät al-Kiyānìyah al-Islämìyah fi al-Dawlah al-Uthmānìyah 18771881 (Beirut: al-Bayān li al-Nashr, 1988), 114.

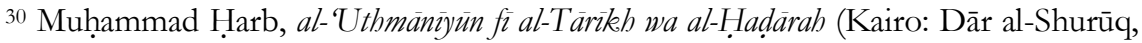
n.d.), 345 .

${ }^{31}$ Farīd Bek, Tärikeh al-Dawlah, 235.

32 Üghalī, al-Dawlah al-Uthmānìyah, 233.

${ }^{33}$ Farīd Bek, Tärikeh al-Dawlah, 243.

34 Elphinston, "Kurds and Kurdistan."
} 
nationalist feeling to divide the nations under the banner of the Ottoman Empire, which was predominantly Muslim, especially the Kurds. ${ }^{35}$ Extreme nationalist groups developed in number known for their jargon said that nationalism must be upheld not only in persuasion but also with the violence. Other nations in Turkey must be limited in space and Turkey belonged to Europe and not part of the Arab Nations. So that the Arabic writings used by the Turks, both formal and informal, were converted into Latin writing.

When the British persuaded Kurdistan to establish a Kurdish united state, the Kurds refused and continued to express their loyalty to Sultan Abdul Hamid II, who had been couped. There was a rebellion of Kurdish tribes against Ittihad, led by Ibrahim Pasa Milali, by preparing an army of about 5,000 troops. Kurdistan fighters succeeded in controlling large parts of Kurdistan. In Sulaimaniyah, Shaykh Sa'id, who had a straight relation to Sultan Abdul Hamid II, revolted with the Kurdish family group (Hamawand). ${ }^{36}$ This worried the Turkish administration, then conspired with the local government to kill him. Aqeedah ties had encouraged the Kurds to help their Arab brothers during the 1911 revolution in Yemen against the Ittihad government. Kurds provided moral and material assistance to Yemeni fighters who battled to get off of the British invaders who were trying to continue to shackle the freedom of their people.

The Kurds had always tried in various ways to continue fighting against the Ittihad, which was a British-backed government that always tried to abolish Islamic Shari'a practiced by people throughout the Arabian Peninsula, Iraq, Iran, and the Ottoman Empire. ${ }^{37}$ In 1908 $\mathrm{AD}$, the Kurds had owned an official magazine called al-Burkan that sought re-enlightenment as an act of resistance to Western propaganda against Islamic Shari'a and Muslims. ${ }^{38}$ One of the famous writers was the Kurdish youth who was remembered and enshrined by Muslims throughout time through historical pages, Badi' az-Zaman Sa'id an-Nursi (1860-1876 AD).

The Ittihad ve Terakki Cemiyeti government banned the bulletin and magazine for the shake of the security of Istanbul and made

35 Muhammad Sayyid Nūrī, Mustaqbal al-Harakah al-Islāmīyah fì Kurdistān al-Trāq (Arbil: al-Tafsīr, 2006), 23-24.

36 al-'Alyāwī, Kurdistān fì 'Ahd Dawlah 'Uthmānìyah, 231.

37 Nūrī, Mustaqbal al-Harakah, 30.

38 Ibrāhīm Khalīl Aḥmad, Wilāyat al-Mūsal: Dirāsah fì Tatawuribā al-Siyāsiỹah 19081922 (Baghdad: Jāmi'ah Baghdād, 1975), 221. 
Turkish people completely worried. Said Nursi always called for continuous-struggling for the safety of the Sultan and the Shari'ah of Islam. ${ }^{39}$ Sa'id Nursi continued to work and struggle, and ignore the danger that would be on him. He also fought against Russia in World War I with his tariqa students with no fear. In 1909, Kurdish intellectuals established a group called Nadi al-Kurdi and opened several branches in many regions of Kurdistan. Kurdish leaders held the inaugurated the organization at the grand mosque in Diyar Bakr, which was attended by clerics and tariqa Syaikh of Sufism. All those present signed their statement of loyalty to Sultan Abdul Hamid II and Islamic Shari'a. They planned an armed struggle to return Sultan Abdul Hamid II to his throne and to re-implement Islamic Shari'a in all Ottoman and Kurdistan regions in particular.

Soon before the eruption of World War I there was a major commotion in the Badils region (Eastern Turkey), led by al-Mala Salim Afandi al-Khaizurani, who joined Kurdish dukes like Rashīd Aghā al-Sulayfan̄i, 'Abd al-Raḥmān al-Sharnafilī, Shaykh Nurizurī alBarifkanī, Shaykh Sa'īd al-Ḥāfid, Shaykh 'Abd al-Salām al-Barzan̄i, demanded to implement Islamic law and expelled the new government formed by Nationalist Secular Turkey. Before the rebellion, Shaykh Abdussalam Al-Barzani had asked the Turkish government of Ittihad to re-apply Islamic Shari'a as before, which was written in the law that stated religion was Islam, and the school applied in the Kurdistan was the Shafi'ite School which was also used in government and justice. Tax levies must be adjusted to the Qur'ān, the Hadīth, and the Shafi'i scholar books and should not be added or subtracted. After the formal abolition of the Khilafah Islamiyah took place in $1924 \mathrm{AD}$, there was turmoil in the entire Kurdistan region and parts of Turkey. This happened in 1925 AD. The Kurds officially rebelled against the new Turkish government. ${ }^{40}$ They demanded to reestablish Islamic Shari'a and appoint one of the sons of Sultan Abdul Hamid II named Salim Afandi as a Muslim caliph. ${ }^{41}$

\footnotetext{
39 Al-Bazyani, Mustaqbal al-Harakah al-Islämìah (Baghdad: Maktabah Syafiq, 1966), 40-47.

40 Evliya Çelebi and Robert Dankoff, The Intimate Life of an Ottoman Statesman: Melek Ahmed Pasha (1588-1662): As Portrayed in Evliya Celebi's Book of Travels (SeyahatName), SUNY Series in Medieval Middle East History (Albany: State University of New York Press, 1991), 115.

41 'Abd al-'Azīz Muhammad Shanawī, al-Dawlah al-Uthmānìyah: Dawlah Islämìyah Muftarā 'Alayhā, Vol. 2 (Kairo: Dār al-Nahdḥah Miṣrīyah, 1988), 332.
} 
Kurdish and Arab may lose hopes over the policies of the Ittihad group (Secular Nationalists). But it did not make the spirit of the Kurds to disappear drastically. When World War I took place, Shi'a and Sunnah scholars agreed to issue a fatwa on the general jihad of Muslims, and it was obliged for every Muslim who could do it morally and materially. The Kurdish scholar (Khaifi Afandi) issued a Fatwa and was welcomed by the public on November 7, 1914, in response to appeals from the caliph, only a symbol, Muhammad Rashād (1909-1918). ${ }^{42}$ Muḥammad Rashād called on all Muslims in the Ottoman Empire to wage jihad and defend the country from the invasion of Russia, Britain, and France.

Kurdish fighters engaged in fighting in Sulaimaniyah, Erbil, Kufri. ${ }^{43}$ They were led by Shaykh Maḥmūd al-Ḥāfid al-Barzanjī, with a total of 2,000 great fighters who were welcomed by the inhabitants of Southern Iraq warmly with enthusiasm along with festive celebrations. Arabs in southern Iraq also joined the resistance against Britain, and they cheered by saying $1 / 3$ of heaven is ours and another $1 / 3$ is Kak Ahmad's and his brothers. The Kurds were fighting not only in the southern part of Iraq but also on the Iranian front, which mostly covered the Caspian Sea and was controlled by the British. The Kurds eventually had to pay a high price in defending Islamic countries, which were not only inhabited by the Kurds but also the Persians and Arabs. Although many of its people were killed and suffered severe economic problems after World War I, the Kurds continued struggling against Britain due to the Islamic Aqeedah encouragement and nationalism. ${ }^{44}$

\section{The Kurds-Turkey Relations after Nation-State}

Kurdish is a nation that has a sense of nationality and national goals that have been formed since the 19th century AD. The Kurdish Nationalist Movement has been influenced by many factors, both externally and internally. ${ }^{45}$ This was due to the poor management of the Ottoman Empire, weakness, setbacks, and corruption; that was

42 E. Attıla Aytekın, "Peasant Protest in the Late Ottoman Empire: Moral Economy, Revolt, and the Tanzimat Reforms," International Review of Social History, Vol. 57, No. 2 (August 2012), 191-227.

${ }^{43}$ Kamāl Muẓhar Aḥmad, Kurdistān fì Sanawàt al-Harb al-'Ālamìyah al-Ūlà Tarjamah Muhmmad Mala Abdul Karim (Libanon: Dār al-Fārābī, 2011), 264-265.

44 Ibid., 265.

45 al-'Alyāwī, Kurdistān fì 'Ahd Dawlab 'Uthmānīyah. 
what the Kurds experienced during that time. Moreover, they often treated awfully badly by the officials and rulers of the Ottoman Empire in Iraq and its surroundings. ${ }^{46}$ The administrators always put down minor rebellions with violence and ignored the demands voiced by people and Kurdish leaders, both community leaders and scholars. Shaykh Majid Khaduri argued about the emergence factor of the rise of nationalism in Kurdistan. 'The insufficient view of local authorities in dealing with Kurdish tribes who extinguish various movements with force and violence or throwing away their leaders or bribing them has provoked anger and curses from the Kurds towards the government". ${ }^{47}$ This type of attempt could not solve problems, and people would always look for answers or even addressed new questions. The growth of Kurdish national awareness in the Arab and European regions under the rule of the Ottoman Empire made the Kurds demand that their national ideals be realized. They requested full autonomy rights due to the Ottoman Empire, which they admit was legally shifting and changing slowly into a country that no longer recognized Islamic Shari'a and became a secular state.

The Kurdish opposition groups existed during the time of Sultan Abdul Hamid II had not yet brought a clear spirit of nationalism and merely a reaction to the political and economic plight. However, during the time of Sultan Abdul Hamid II, Kurds, which was an ignored and an outcast nation, had become a nation of concern to Sultan Abdul Hamid II. ${ }^{48}$ Many of the Kurdish held important positions especially as military leaders who strictly upheld Islamic Shari'a and dedicated their loyalty to the Sultan. In this period, the Kurds were equipped with their autonomous rights. But this privilege changed after the Ittihad ve Terakki Cemiyeti party controlled the government. ${ }^{49}$

The Turkish movement had changed its taboos when the Ittihad party carried out a revolution in 1908 AD. The Kurds knew they had been made scapegoats to destroy Sultan Abdul Hamid II. Kurdish leaders could feel this and the Ittihad Party tried to erase the history and background of their nationalism. They opined, "The

46 Mājid Muhammad Yūnus, al-Fursān al-Hamììyah 1891-1923 (Mosul: Jāmi'ah Mosul, 2006), 265-270.

47 Aytek1n, "Peasant Protest in the Late Ottoman Empire."

48 Gábor Ágoston and Bruce Alan Masters (eds.), Encyclopedia of the Ottoman Empire, Facts on File Library of World History (New York, NY: Facts On File, 2009), 56.

${ }^{49}$ Farīd Bek, Tärikeh al-Dawlah, 124. 
Turkification politics launched by the Ittihad ve Terakki Cemiyeti party was not the same as Turkey in the Ottoman Empire. This encouraged nations like Arabs, Albania, Kurds, and others to reconsider their fate and the sacrifices they had made". This was what made the nations under the banner of star moon established national organizations that were then formed by the British, French, Italian, and then Russian invaders as puppet states. They controlled the countries and depleted their natural resources.

The Kurdish national political activity started to form slowly. In Astana, at the end of 1908, a Kurdish Club formed on the initiative of Amin Badarkhan, and newspapers called Kurd Corporation and Ascent were published. The papers aroused the enthusiasm of the Kurds to establish an independent Kurdish state. The motto was Kurdistan for the Kurds. ${ }^{50}$ Then, a new group and organization established by the end of 1910; that was the Amal party. Kurdish newspapers were written in two languages, Arabic and Kurdish, with the Kurdistan Sun symbol. In 1913 AD, Shaykh al-Hafid joined the sons of Badarkhan, to unite and set Kurdistan free from the influence of the Turks and established a Federal state. After world war I, the Kurds fought in new ways and means through magazine and newspaper sheets and organized-political activities. ${ }^{51}$ Kurdish newspapers spread out in 1908 called Syarq al-Kurdistan

A newspaper that had stopped publishing since 1902 AD republished its edition. This media was managed by Ahmad Tsarya Badarkhan. While in Diyar Bakr in 1909 AD, a new publication appeared with the name Baynama/al-Ahad. Several bulletins were published in $1912 \mathrm{AD}$, one of which was the Kurdistan bulletin and the Yakbun/Ittihad magazine in 1913 AD. ${ }^{52}$ There had been many strives made by Kurdish political organizations and disseminated the fight through printed media. This was considered as an effective endeavor to spread Kurdish thoughts and culture and aspirations to become an independent and sovereign nation even though pressures and threats constantly hit both from outside and inside. ${ }^{53}$

\footnotetext{
${ }^{50}$ Black Antony, Kurdistan: in the Shadow of History (London: Random House, 1997), 69.

51 Qāsim Khalf 'Āṣi al-Jamîlī, al-Trāq wa al-Harakah al-Kamālìyah 1919-1923 (Baghdad: Jāmi'ah Baghdād, 1999), 90-91.

52 Ibid.

53 Ibid.
} 
At the beginning of the 20th century, Kurdish leaders began to think of establishing a country after the Ottoman Empire fell in world war I in 1918 AD. They named their country "Kurdistan." The victorious allies had given an illustration in the agreement that the nations of each region of the Ottoman Empire who did not speak Turkish would be freed according to the Sayfer Agreement of 1920. However, that hope was always as distant as ever since the division of territory did not allow the Kurds to rule their own country as their territory had been broken by maps drawn by several countries of the winners of world war I in the Treaty of Lausanne. ${ }^{54}$ This caused Kurds to become minority ethnic groups in these countries, such as in Iran, Iraq, Syria, and Turkey. In 1970, the Baghdad government, through the al-Ba'ts party, offered a truce and granted autonomy. However, the agreement ended and war broke out in 1974. A year after, there was a split in the Kurdistan Democratic Party. Kurdish politician named Jalal Talibani founded a party called the Kurdistan National Democratic Union. ${ }^{55}$

In 1988 after the Iraq and Iran wars were over, the city of Halbajah (Iraqi Kurdistan) attacked by chemical weapons under Saddam Hussein's order because the Kurds helped Iran in its war with Iraq under the command of the Kurdish KDP party. ${ }^{56}$ The tribal disunity between the Kurds made the Kurds in Iraq unable to have their own country and only became a political game of countries who had an interest in Iraq, Iran, Syria, and Turkey. No exception Israel's influence had affected the general election in Irbil, the Iraq region. The scope of these areas was planned by ISIL to be controlled and added to the existing chaos. ${ }^{57}$

\section{Concluding Remarks}

Kurdistan is a strategic region that is integrated into an area where it hardly possible to find a society with the same ethnic group within the same area. It has abundant natural resources and calculated

\footnotetext{
${ }^{54}$ Farīd Bek, Tärikkh al-Dawlah, 121.

${ }_{55}$ Nader Entessar, Kurdish Politics in the Middle East (Lanham: Lexington Books, 2010), 14.

56 Martin van Bruinessen, "The Kurds between Iran and Iraq," MERIP Middle East Report, No. 141 (July 1986), 14.

${ }^{57}$ Masdar Hilmy, "Genealogi dan Pengaruh Ideologi Jihadisme Negara Islam Iraq dan Suriah (NIIS) di Indonesia," Teosofi: Jurnal Tasawnf dan Pemikiran Islam, Vol. 4, No. 2 (September 17, 2015), 404.
} 
areas in the trade and military routes. This has made Kurdistan, from time to time, a favorable object to be fought over by various countries, nations, and empires that have ever existed, especially the Safavid kingdom and the Ottoman Empire. Likewise, after the fall of the Ottoman Empire, there were modern and powerful states that fought for influence in the Kurdistan region such as Russia, Britain, Germany. The United States and Israel are the most influential countries in Kurdistan as they directly handle the administration and politics.

Kurdish people realized that they were part of the Islamic ummah, with total freedom in determining and revealing their identity. In the Kurdistan magazine published in 1889 AD, it was written: "every Muslim wants the Ottoman Empire to remain when a disease has lodged in the body of this country, we must immediately give the cure and eliminate the cause of the disease because the health of the country (Ottoman) is our health too, the death of the Ottoman Empire is our death too." The Kurds also played a role in the Ittihad ve Terakei Cemiyeti party in 1889, to get independence or at least autonomy in a broad meaning for the Kurds. However, this request, which included the vision and mission of the Kurds, contradicted the policy of the central Ittihad party. After the coup of Sultan Abdul Hamid, the gap between the Kurds and the Ottoman Empire widened. They (Turkish secular groups) did not recognize other nationalism in their territory besides Turkish. It was the reason for the leaders of the Kurds to keep fighting for their identity as Kurdish people and their freedom in the Ottoman state. Subsequently, underground movements were formed and official associations published magazines and newspapers to raise national and state awareness for all Kurds.

Even though Ittihad ve Terakki Cemiyeti marginalized the Kurds, they remained people with good loyalty to the Ottoman Empire. They considered the Ottoman Empire as relatives who must be defended. The Turks dangerously exploited the Kurds and forgot them in their favor, especially in the period after the coup over Sultan Abdul Hamid II carried out by a secular party. At the time of Sultan Abdul Hamid II, the spirit of nationalism had not yet seen clearly as religious understanding and attitudes in the Ottoman Empire which was tied by aqidah Islamiyah. This was a bond that united the entire ethnic groups in one creed like one family, the Muslim family. But when the 
Kurds felt the tendency of Turkish nationalism as emerged by the Ittihad party, which could melt their identity into the identity of Turkish, they started to respond to the threat. They began to grow a shared sense of national identity and landed consciousness because the Islamic faith in the country was no longer existing and had been transformed into a secular nationalism initiated by the Ittihad party and then by Kemal Attaturk, who abolished the Ottoman Empire.

\section{Bibliography}

Ágoston, Gábor and Masters, Bruce Alan (eds.). Encyclopedia of the

Ottoman Empire, Facts on File Library of World History. New York, NY: Facts On File, 2009.

Aḥmad, Ibrāhīm Khalīl. Wilāyat al-Mūsal: Dirāsah fì Tatanurihà alSiyāsiyah 1908-1922. Baghdad: Jāmi‘ah Baghdād, 1975.

Aḥmad, Kamāl Muẓhar. Dawr al-Sha'b al-Kurdī fì Thawrah al-Tshrin alIrāqìyah. Baghdad: Maṭba'at al-Hawādith, 1978.

----. Kurdistān fì Sanawāt al-Harb al-'Álamìyah al-Ūlà Tarjamah Mubmmad Mala Abdul Karim. Libanon: Dār al-Fārābī, 2011.

'Alyāwī (al), 'Abd Allah. Kurdistān fi' 'Abd Dawlah 'Uthmānìah 18511914 Dirāsah fì al-Tärikh al-Siyāsì. Sulaimaniyah: Matba'ah Baghdad, 2005.

Antony, Black. Kurdistan: in the Shadow of History. London: Random House, 1997.

Asatrian, Garnik. "Prolegomena to the Study of the Kurds," Iran and the Caucasus, Vol. 13, No. 1, 2009.

Aykut, Ebru. "Judicial Reforms, Sharia Law, and the Death Penalty in the Late Ottoman Empire," Journal of the Ottoman and Turkish Studies Association, Vol. 4, No. 1, 2017.

Aytekın, E. Attıla. "Peasant Protest in the Late Ottoman Empire: Moral Economy, Revolt, and the Tanzimat Reforms," International Review of Social History, Vol. 57, No. 2, August 2012.

Bazyani (al). Mustaqbal al-Harakah al-Islämìah. Baghdad: Maktabah Syafiq, 1966.

Bek, Muhammad Farīd. Tärīkh al-Dawlah al-Alìyah al-Utmānìyah. Beirut: Dār al-Nafāis, 2009.

Beriker-Atiyas, Nimet. "The Kurdish Conflict in Turkey: Issues, Parties, and Prospects," Security Dialogue, Vol. 28, No. 4, December 1997. 
Boyle, John Andrew and Arberry, A. J. (eds.). The Cambridge History of Iran. Vol. 5: The Seljuq and Mongol Periods, Repr. Cambridge: Cambridge Univ. Press, 2007.

Bruinessen, Martin van. "The Kurds between Iran and Iraq," MERIP Middle East Report, No. 141, July 1986.

Çelebi, Evliya and Dankoff, Robert. The Intimate Life of an Ottoman Statesman: Melek. Abmed Pasha (1588-1662): As Portrayed in Evliya Celebi's Book of Travels (Seyahat-Name), SUNY Series in Medieval Middle East History. Albany: State University of New York Press, 1991.

Elphinston, W. G. "Kurds and Kurdistan," International Affairs, Vol. 25, No. 2, April 1949.

Entessar, Nader. Kurdish Politics in the Middle East. Lanham: Lexington Books, 2010.

Faroqhi, Suraiya and İnalc1k, Halil eds. An Economic and Social History of the Ottoman Empire, Vol. 2: 1600-1914, 1. paperback ed., reprinted. Cambridge: Cambridge Univ. Press, 2004.

Foltz, Richard. 'The 'Original' Kurdish Religion? Kurdish Nationalism and the False Conflation of the Yezidi and Zoroastrian Traditions," Journal of Persianate Studies, Vol. 10, No. 1, June 1, 2017.

Gharīb, Edmund. al-Harakah al-Qawmīyah al-Kurdìyah. Beirut: Dār alNahār, 1973.

Harb, Muhammad. al-Uthmānìyūn fì al-Tärikh wa al-Hadärah. Kairo: Dār al-Shurūq, n.d.

Hilmy, Masdar. "Genealogi dan Pengaruh Ideologi Jihadisme Negara Islam Iraq dan Suriah (NIIS) di Indonesia," Teosofi: Jurnal Tasawnf dan Pemikiran Islam, Vol. 4, No. 2, September 17, 2015.

Jamìlī (al), Qāsim Khalf 'Āṣì. al-Irāq wa al-Harakah al-Kamālīyah 19191923. Baghdad: Jāmi'ah Baghdād, 1999.

Kharudakī, Maryani. al-Kurd wa al-Siyāsah al-Khärijzyah al-Amrīkìyah. Beirut: Dār al-Fārābī, 2003.

Meirison. "Kurds, Islam, and Secularism," Jurnal Madania, Vol. 23, No. 1, June 2019.

Murād, Khalīl 'Alī. Tärìkh al-Trāq al-Idārì wa al-Iqtișāì fì 'Abd alUthmānì 1638-1750. Baghhad: Jāmi'at al-Baghdād, 1875.

Muṣtafā, Aḥmad 'Abd al-Rahịm 'Abd al-Rahịm. Fì Ușül al-Tärìkh alUthmānì. Kairo: Dār al-Shurūq, 1982.

Nikitin, Basil. al-Akrād. Kairo: Dār Sahāb, 2018. 
Nūrī, Muhammad Sayyid. Mustaqbal al-Harakah al-Islämīyah fì Kurdistān al-Trāq. Arbil: al-Tafsīr, 2006.

Orhan, Mehmet. "Kurdish Rebellions and Conflict Groups in Turkey during the 1920s and 1930s," Journal of Muslim Minority Affairs, Vol. 32, No. 3, September 2012.

Quataert, Donald. The Ottoman Empire, 1700-1922. Cambridge, UK; New York: Cambridge University Press, 2005.

Shanawī, 'Abd al-'Azīz Muhammad. al-Dawlah al-Uthmānīyah: Dawlah Islämìah Muftarā 'Alayhā, Vol. 2. Kairo: Dār al-Nahdhah Mișriyah, 1988.

Shaw, Stanford J. and Shaw, Ezel Kural. History of the Ottoman Empire and Modern Turkey. Vol. 1: Empire of the Gazis: The Rise and Decline of the Ottoman Empire: 1280-1808, Reprinted. Cambridge: Cambridge Univ. Press, 1995.

Shodiq, Muhammad. "Eksistensi dan Gerakan Dakwah Tarekat Siddîqiyah di Tengah Masyarakat Urban Surabaya," Teosofi: Jurnal Tasawnf dan Pemikiran Islam, Vol. 5, No. 2, 2016.

Syanawi, Rauf. al-Naz'ät al-Kiyāniyah al-Islämiyah fì al-Dawlah alUthmānìyah 1877-1881. Beirut: al-Bayān li al-Nashr, 1988.

Ūghalī, Akmal al-Dīn Iḥsān. al-Dawlah al-Uthmānīyah: Tärikh wa Hadārah. Istanbul: Markaz Abhāath al-Tārīkh, 2011.

Yūnus, Mājid Muhammad. al-Fursān al-Hamidìyah 1891-1923. Mosul: Jāmi'ah Mosul, 2006.

Zakī, Muhammad Amīn. Tärīkh al-Duwal wa al-Imārah al-Kurdīyah. Kairo: Dār al-Miṣr, 1948. 